\section{Jennifer Segal Diascro Joins APSA as Director of Institutional Programs}

\section{Coming in the NEXT ISSUE}

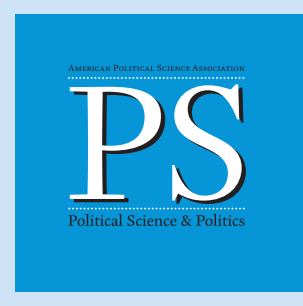

J ennifer Segal Diascro has joined the APSA as director of institutional programs. Jennifer brings nearly 20 years of experience in political science to the APSA. Most recently, she served on the faculty of the department of government at American University (2002-10). She was previously an associate professor at the University of Kentucky, where she was on the faculty of the department of political science from 1995 to 2002. During that time, she was also a Supreme Court Fellow at the United States Sentencing Commission (2000-01). She earned her Ph.D. in judicial politics from the Ohio State University in 1995 .

As director of institutional programs at the APSA, Jennifer will have a primary role in advancing the APSA's departmental programs and support for department chairs. Additionally, Jennifer will be responsible for institutional research, particularly the development and administration of department and graduate program surveys. She will act as the APSA's liaison to the Departmental Services Committee; the Committee on the Status of Women in the Profession; and the Committee on the Status of Lesbians, Gays, Bisexuals and the Transgendered (LGBT) in the Profession. Jennifer also will provide association staffleadership for President Pateman's Ad Hoc Committee on Workable Solutions to Advancing Women in the Discipline.

Jennifer's research interests focus on the politics of the judiciary and include work on gender, racial, and ethnic diversity and representation on the federal bench; the mass media and the courts; public opinion and the Supreme Court; and federal sentencing. Her work has been published in Political Research Quarterly, Judicature, the American Review of Politics, and the Federal Sentencing Reporter. Additionally, Jennifer is co-author of Television and the Supreme Court: All the News That's

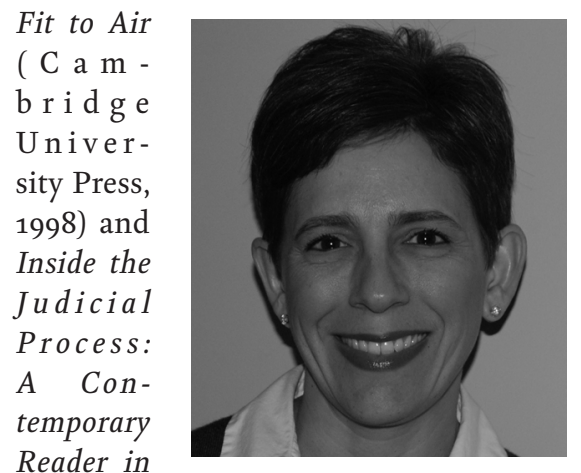

Law, Politics and Courts (Houghton Mifflin, 2006). She authored a chapter entitled "Public Education for Men Only: United States v. Virginia (1996)" in Creating Constitutional Change: Clashes over Power and Liberty in the Supreme Court (University of Virginia Press, 2004) and coauthored "Judicial Elections in the News" in Running for Judge (New York University Press, 2007).

Jennifer is an accomplished teacher. Among her repertoire of courses is judicial politics (undergraduate and graduate), media and politics, civil liberties and constitutional law, the American jury, U.S. politics, women in politics (reproductive and family law, undergraduate and graduate), and research design. She has been nominated for and received several teaching awards.

Jennifer brings a number of administrative experiences and accomplishments to her role at the APSA. In addition to serving on many faculty search committees and doctoral recruitment committees and participating in undergraduate recruitment and retention events, she played a significant role in program assessment at Kentucky, served for two years as faculty advisor for doctoral students in the department of government at American University, and served for three years on a university-wide committee that wrote American's first parental leave policy in 2009.
A preview of some of the articles that will be published in the April issue

\section{SYMPOSIUM}

Pracademics: Mixing an Academic Career with Practical Politics

Christopher Mooney and Michael McDonald, guest editors

\section{FEATURES}

More than a Dime's Worth: Using State Party Platforms to Assess the Degree of American Party Polarization Daniel J. McCoffey

Wikipedia as a Data Source for Political Scientists: Accuracy and Completeness of Coverage

Adam R. Brown

\section{PROFESSION}

Ranking Scholarly Publishers in Political Science: An Alternative Approach James C. Garand

The Job Market's First Steps: Harnessing Research Tools to Avoid Wasted Time and Embarrassing Mistakes

Ryan T. Moore

\section{TEACHER}

Learning from Popular Culture: The "Politics" of Competitive Reality Television Programs

David Dreyer

Getting Political Science in on the Joke: Using The Daily Show and Other Comedy to Teach Politics

Staci L. Beavers

Speaking with an Accent: Some Practical Advice for Foreign First-Time Teachers Ramiro Berardo 